\title{
The contribution of prof. Tadeusz Lewicki (1906-1992) to Islamic and West African studies
}

Professor Tadeusz Lewicki was one of the most famous Polish scholars of Oriental studies and teachers of several generations of Polish orientalists. His areas of interest included the material, intellectual, social and religious history of Africa and Central Europe in the medieval period. His research is an impressive and valuable work of scholarship inspired by the Arabic sources on the history of the Ibadites and of the Slavic peoples. He also catalogued the eighth-and ninth-century Arabic coins found in the Polish lands. His research concerning the economic life and trade relations of the Slavs with the countries of the East gives us useful information about the formation of the state in northern Poland.

"Scholar, partisan, traveller and erudite" are the words describing Professor Lewicki in the commemorative book dedicated to him. ${ }^{1}$ Professor Lewicki was able

\footnotetext{
${ }^{1}$ Cf. A. Zaborski, Min bilād aș-Șaqāliba ilā bilād as-Sūdān - od słowiańszczyzny po Sudan. Prof. Tadeusza Lewickiego dorobek arabistyczny, [in:] Studia Orientalia Thaddaeo Lewicki Oblata, Kraków 1994, p. 7; A. Zaborski, Tadeusz Lewicki (1906-1992), [in:] Uniwersytet Jagielloński. Złota Księga Wydziału Filologicznego, ed. J. Michalik, W. Walecki, Kraków 2000, p. 619-623. A. Małecka, Wspomnienie o Profesorze Tadeuszu Lewickim (1906-1992), http://www.lwow.com.pl/lewicki.html (quoted 12.06.2012); W. Mańczak, Prace romanistyczne profesora Tadeusza Lewickiego, [in:] Studia Orientalia Thaddaeo Lewicki Oblata, Kraków 1994, p. 15-17; Tadeusz Lewicki, Archive of the Warsaw Uprising Museum, http://www.1944.pl/historia/powstancze-biogramy/Tadeusz_Lewicki_1 (quoted 12.07.2012); Tadeusz Lewicki - strona główna Uniwersytetu Wrocławskiego, http://www.uni.wroc. pl/o-nas/godno\%C5\%9Bci-honorowe/doktorzy-honoris-causa/tadeusz-lewicki (quoted 13.07.2012); J. Rozynek, J. J. Ziółkowski, Doktorzy honoris causa Uniwersytetu Wrocławskiego 1948-2002, Wrocław 2002, p. 153; B. Michalak, Sesja naukowa poświęcona pamięci profesora Tadeusza Lewickiego, "Przegląd Orientalistyczny" 1-2 : 1994, p. 94; K. Maciuszak, Z historii orientalistyki na Uniwersytecie Jagiellońskim, "Alma Mater" 120-121 : 2009-2010, p. 139; no. 1; Kolokwium naukowe ku czci profesora Tadeusza Lewickiego w pierwsza rocznicę śmierci (1993), "Africana Bulletin” 42: 1994, p. 115. Professor Tadeusz Lewicki was widely honored by scientists in the scientific periodical "Rocznik Orientalistyczny”: Studia orientalistyczne poświęcone pamięci Profesora Tadeusza Lewickiego (Orientalia memoriae Professoris Thaddaeo Lewicki dedicata, "Rocznik Orientalistyczny" 50 : 1995, no. 1-2.
} 
to combine genuine scholarship with a genius at storytelling and ability to communicate complex events in a supremely accessible way. Students recalled Professor Tadeusz Lewicki as a memorable instructor who was great in what he did. ${ }^{2}$

\section{Scientific biography}

Tadeusz Lewicki was born in Lviv (Polish: Lwów), present day Ukraine, on 29 January 1906. It worth mentioning that Lwów belonged to the Kingdom of Poland and then to the Second Polish Republic till the year 1939. Lewicki grew up in Lwów and in 1919, as a fourteen-year-old boy, participated in the so-called defence of Lwów against the Ukrainian nationalists forces. He belonged to the young volunteers called "Orlęta Lwowskie" (Lwów Eaglets).

After having attended the 8th Grammar School named after King Casimir the Great in Lwów in 1925 he studied at the Humanistic Faculty of the Jan Kazimierz University in Lwów. Focusing on Oriental studies, he spent three years in Paris, studying Semitic languages. The aim of this difficult work was his dream to pursue a career in diplomacy. In 1931 he returned to University in Lwów where he received the doctor of philosophy degree, presenting his dissertation on the history of North Africa in the early medieval period, written under the supervision of Professor Zygmunt Smogorzewski (1884-1931). ${ }^{3}$ In 1931, he left for Paris for a two-year scholarship at the Sorbonne and Collége de France. During his studies in France he collected material concerning the history of Slaves and Arabic philology on the basis of the works of Al-Idrīsī (1099-1165 or 1166), especially Nuzhat al-muštāq fi’htirāq al-āfāq (نز هة المشتاق في اختراق الآفاق-Tabula Rogeriana). He was also fascinated by the history of Ibādiyya. For that reason, he decided to spend six months in M'zab, first of all in Wargla, which was the capital of the late medieval M'zab, Ibāọī political entity descended from the earlier Rustamid policy. There Lewicki gathered new source material and studied the old manuscripts, trying to discover information about the Muslim group Ibāḍ̄i

After his return to Lwów in 1934 Lewicki was employed as an assistant lecturer in the Department of Ancient History of the Jan Kazimierz University till March 1940, when the university was taken over by the Russian communists and renamed as the Ukrainian National University. World War II interrupted Professor Lewicki's scientific activities. Unable to earn his livelihood, in 1940-1942 he worked

${ }^{2}$ Cf. J. Bubka, B. Ostafin, Tadeusz Lewicki (1906-1992), [in:] Studia Orientalia Thaddaeo Lewicki Oblata, Kraków 1994, p. 171.

${ }^{3}$ Zygmunt Smogorzewski (1884-1931) - Arabist and orientalist, diplomat of the tsar's Russia from 1912 and Polish diplomat in 1919-1924, professor of the Jan Kazimierz University in Lwów, head of the Department of Oriental Studies at the Jan Kazimierz University in Lwów (it was closed after his death in 1931); co-founder of the Polish Oriental Society (1922). He conducted linguistic research in the countries of Maghreb (the first expedition in 1913). Cf. A. Kuczyński, Korzenie i wspótczesność polskich badań etnologicznych w Afryce, "Etnografia Polska" 38 : 1994, no 1-2, p. 136, 142. 
as a builder and at the same time he was engaged in underground activities against the German-Nazi occupants, fighting in the Union of Armed Struggle (Związek Walki Zbrojnej), renamed in 1942 as Home Army (Armia Krajowa). ${ }^{4}$ The participation in this organization facilitated Lewicki to escape from the areas under the Soviet occupation, including Lwów, to the region under the German occupation - he came to Warsaw. Afterwards Home Army also helped him to avoid the Gestapo repression. Being aware of the danger of his underground activities caused that Lewicki kept his true identity and political allegiance in secret, changing his name twice (Teofil Laskowski and Zygmunt Woźniak). The underground organization assigned Lewicki to work in the microphotographic section of the Propaganda and Information Office of Home Army. In the autumn of 1943, he participated in the fights in the region of Zamość and in 1944, he fought in the Warsaw Uprising. Lewicki was captured by the Wehrmacht in November 1944 and as a Polish prisoner of war he was interned in the Officers' Camp in Murnau (Bavaria). When the camp was liberated in 1945 by the American Forces, Lewicki decided to spend several months in the American Zone, serving in the guard squads. ${ }^{5}$ War fate caused that in 1946 this great orientalist taught Polish history and literature both at the Middle School and Mechanical College run by the Polish II Corps in Italy (Fermo). Finally, Lewicki was evacuated with the Polish Army of General Anders to England (Millom). ${ }^{6}$ It is worth stressing that the so-called Anders' Army, being an anti-communist organization, had strong connections with the Orient. The army left the Soviet Union through Ashkhabad in Uzbekistan to the railhead at Mashhad in Persia, joining the British High Command in the Middle East, then crossed through Persia, Iraq, Palestine, Italy to England. ${ }^{7}$

${ }^{4}$ Związek Walki Zbrojnej, abbreviation: ZWZ, usually translated as Union of Armed Struggle (or Union for Armed Struggle or Association of Armed Struggle or Association for Armed Struggle) was a Polish underground army formed in Poland following the invasion in September 1939 by Germany and the Soviet Union. In January 1940, the Union of Armed Struggle was divided into two parts: lands under the German occupation commanded by Colonel Stefan Rowecki with the headquarters in Warsaw and the areas under the Soviet occupation, commanded by General Michał Tokarzewski-Karaszewicz, headquartered in Lwów. On 14 February 1942, ZWZ was renamed as Armia Krajowa (Home Army). Cf. S. Korboński, The Polish Underground State: A Guide to the Underground, 1939-1945, Boulder 1979.

${ }^{5}$ Information from the Archive of the Warsaw Uprising Museum: Tadeusz Lewicki: military rank - second lieutenant; no. card: AK120250; place of birth: Lwów; names of parents: Tadeusz - Helena Ostrowska; conspiration name: Zygmunt Woźniak; pseudonyms: "Tomasz," "Rogala"; participation in the underground organization: 1939-1944; Main command of the Home Army - Department VI BiP (Propaganda and Information Office); 1943 PSW (Press war reporter); 1944 Department of the Home Army - I circle "Radwan" (Downtown) - grouping "Chrobry II" - I Battalion "Lech Żelazny" - $3^{\text {rd }}$ company; Combate route: Downtown North; fate after the Warsaw Uprising: German captivity - prisoner no. 101905. Cf. Tadeusz Lewicki, The Archive of the Warsaw Uprising Museum, http:// www.1944.pl/historia/powstancze-biogramy/Tadeusz_Lewicki_1 (quoted 12.07.2012); J. Bubka, B. Ostafin, Tadeusz Lewicki (1906-1992)..., p. 169.

${ }^{6}$ Cf. Wspomnienie o Profesorze Tadeuszu Lewickim (1906-1992)..., p. 1; J. Bubka, B. Ostafin, Tadeusz Lewicki (1906-1992)..., p. 169.

${ }^{7}$ Cf. W. Anders, An Army in Exile: The Story of the Second Polish Corps, Nashville 2004. 
After his numerous wartime experiences Professor Tadeusz Lewicki returned to Poland in October 1947 and was employed in the Polish Academy of Arts and Sciences (Polska Akademia Umiejętności). In 1948 he was appointed Head of the Department of Oriental Philology (which in 1972 was renamed as the Institute of Oriental Philology). After the war Lewicki continued the work which he had undertaken during his research in Paris (1932-1934), which resulted in the publication of Poland and Neighbouring Countries as described by the Arabian Geographer al-Idrīsi in the Book of Roger. ${ }^{8}$ This book had been finished properly by the Author before 1939 but some parts were during the war. Lewicki had to complete his work, and it was the basis to receive the degree of doctor habilitus in 1949. In 1954 he was appointed as professor and in 1961 Lewicki received the title of full Professor.

Besides his scientific and didactic work at the Jagiellonian University Professor Lewicki was involved in the activities of the Polish Academy of Sciences (PAN) as Head of the Department of Numismatics at the Institute of History and Material Culture $^{9}$ (in 1969 the Department of Numismatics was transferred to the Polish Academy of Sciences to the Institute Oriental Philology at the Jagiellonian University, where it closed in $2012^{10}$ ). In 1960 Tadeusz Lewicki was appointed Dean of the Faculty of Philology of the Jagiellonian University and he worked as Head of the Faculty for two years. At that time Tadeusz Lewicki was an Arabist of international fame and in 1959 he founded the periodical Folia Orientalia. For many years he was the chairman of the Polish Oriental Society (1958-1962, 1966-1980) ${ }^{11}$ and held the Honourable Chair of the Committee on Oriental Studies of the Polish Academy of Sciences in 1984-1992. ${ }^{12}$ He belonged to numerous international societies:

${ }^{8}$ Cf. T. Lewicki, Polska i kraje sasiednie w świetle "Księgi Rogera," geografa arabskiego z XII w. al-Idrīsī'ego. Część I: Uwagi ogólne, tekst arabski, tłumaczenie (Pologne et les pays voisins dans le "Livre de Roger"), Kraków 1945.

${ }^{9}$ Cf. T. Lewicki, Sur l'Activité du Centre d'Etudes Numismatiques de l'Institut d'Histoire de la Culture Matérielle, "Ergon” 1 : 1958, p. 295-297; T. Lewicki, Z działalności naukowej Zakładu Numizmatyki IHKM, "Kwartalnik Historii Kultury Materialnej” 4 : 1955, p. 818-820; K. Maciuszak, Z historii orientalistyki na Uniwersytecie Jagiellońskim..., p. 139; M. Salamon, Sekcja Numizmatyczna Komisji Archeologicznej Oddziału Polskiej Akademii Nauk w Krakowie, "Notae Numismaticae" 2: 1997, p. 207.

${ }^{10}$ Cf. Zarzadzenie nr 14 Rektora UJ z 22 lutego 2012 roku, W sprawie: likwidacji Pracowni Źródet Orientalnych i Numizmatyki w Instytucie Orientalistyki Wydziału Filologicznego UJ, http:// www.bip.uj.edu.pl/dokumenty/zarzadzenia-rektora (quoted 22.07.2012); Decyzja $\mathrm{nr} 18$ Kanclerza Uniwersytetu Jagiellońskiego z 21 marca 2012 roku w sprawie: powołania komisji do inwentaryzacji zbiorów pozostajacych w dyspozycji Pracowni Źródet Orientalnych i Numizmatyki, http://www.bip. uj.edu.pl/documents/1384597/2379255/dec_18_2012.pdf(quoted 22.07.2012).

${ }^{11}$ Polskie Towarzystwo Orientalistyczne - prezesi, http://www.orient.uw.edu.pl/pto/index. php?option=com_content\&view=article\&id=41\&Itemid=39 (quoted 12.07.2012).

${ }^{12}$ Cf. M. Kozłowska, Komitet Nauk Orientalistycznych, [in:] Polska Akademia Nauk 1952-2002: placówki i komitety, ed. L. Kuźnicki, Warszawa 2002, p. 332-334. 
Académie des Sciences d'Outre-Mer (Paris, from 1975), ${ }^{13}$ Royal Asiatic Society (London) ${ }_{1}^{14}$ Association Internationale d'Etudes des Civilisations Méditerranéennes (Malta). ${ }^{15} \mathrm{He}$ also held Doctor Honoris Causa from Wrocław University. ${ }^{16}$

After his retirement in 1976 Professor Lewicki continued his studies of the Arabic sources, helping young orientalists in their scientific research.

\section{List of Lewicki's Islamic and West African studies}

Professor Lewicki published nearly 500 scientific papers, articles and books. ${ }^{17}$ His works concern the application of Arabic sources to the history of the Ibādites and the medieval history of Central Europe.

The following works are, in my opinion, the most important research on Islam in West Africa, especially on Ibāạiyya:

\begin{tabular}{|c|c|c|}
\hline 1. & 1934 & $\begin{array}{l}\text { Une chronique ibādite : Kitāb al-siyar d'Abu 'l-Abbās Ahmad aš-Šammāhn̄, "Revue des Etudes } \\
\text { Islamiques" } 1: 1934 \text {, p. 59-78. }\end{array}$ \\
\hline 2. & 1934 & $\begin{array}{l}\text { De quelques textes inédits en vieux berbère provenant d'une chronique ibädites anonyme," "Revue } \\
\text { des Études Islamiques" } 3: 1934 \text {, p. 275-296. }\end{array}$ \\
\hline 3. & 1936 & Le Culte du bélier dans la Tunisie musulmane, "Revue des Etudes Islamiques" 2 : 1935, p. 196-200. \\
\hline 4. & 1941 & $\begin{array}{l}\text { Al- Ibāḍ̄ya, [in:] Handwörterbuch des Islam, ed. A. J. Wensinck, J. H. Krammers, Leiden 1941, } \\
\text { p. 179-181. }\end{array}$ \\
\hline 5. & 1948 & On Some Libyan Ethnics in Johannis of Corippus, Kraków 1948. \\
\hline 6. & 1955 & 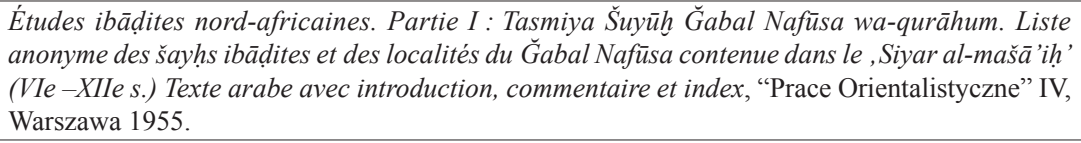 \\
\hline 7. & 1955 & A propos d'une liste de tribus berbéres d'lbn Hawkqal, "Folia Orientalia" 1 : 1955, p. 203-255. \\
\hline 8. & 1957 & $\begin{array}{l}\text { La répartition des groupements ibddites dans l'Afrique du Nord au Moyen Âge, "Rocznik } \\
\text { Orientalistyczny" } 21: 1957, \text { p. 304-343. }\end{array}$ \\
\hline 9. & 1958 & Les subdivisions de l'Ibāḍyya, “Studia Islamica” 9: 1958, p. 71-82. \\
\hline 10. & 1958 & $\begin{array}{l}\text { Une langue romane oubliée de l'Afrique du Nord. Observations d'un arabisant, "Rocznik } \\
\text { Orientalistyczny" } 17: 1958, \text { p. 415-480. }\end{array}$ \\
\hline 11. & 1959 & Les ibāḍtites en Tunisie au Moyen Age, Roma 1959. \\
\hline 12. & 1959 & Sur la ville comane de Qay, "Vznik a pocatky slovanu" 2 : 1958, p. 13-18. \\
\hline 13. & 1959 & Les ibādites dans l'Arabie du Sud au moyen âge, "Folia Orientalia" 1: 1959, p. 3-17. \\
\hline
\end{tabular}

${ }^{13} \mathrm{Cf}$. Académie des Sciences d'Outre-Mer-members décédés, http://www.academieoutremer.fr/ academiciens $/$ ?num $=160 \& \mathrm{gM}=1 \&$ gtype $=($ quoted 12.07 .2012$)$.

${ }^{14} \mathrm{Cf}$. H. Wang, Famous and not-so-famous people associated with the Royal Asiatic Society, http:// thebritishmuseum.academia.edu/HelenWang/Papers/1115148/Famous_and_not-so-famous_people_ associated_with_the_Royal_Asiatic_Society (quoted 12.07.2012).

${ }^{15}$ J. Bubka, B. Ostafin, Tadeusz Lewicki (1906-1992)..., p. 170.

${ }^{16}$ J. Rozynek, J. J. Ziółkowski, Doktorzy honoris causa Uniwersytetu Wrocławskiego 1948-2002..., p. 153.

${ }^{17}$ Cf. W. Zajączkowski, Tadusz Lewicki, "Folia Orientalia" $12: 1970$, p. 7-47 (Bibliography of Lewicki's works till 1970); J. Bubka, B. Ostafin, Tadeusz Lewicki (1906-1992)..., p. 176 (they give the number of Lewicki's works); Soobshcheniia pol'skikh orientalistov (Bibliography), Moscow 1961, p. 107-09 (Bibliography of Lewicki's works till 1960). 
14. 1960 Quelques extraits inédits relatifs aux voyages des commerçant et des missionaires ibädites nordafricains au pays du Soudan occidental et central au Moyen Age, "Folia Orientalia" 2 : 1960-1961, p. $1-27$.

\begin{tabular}{|c|c|c|}
\hline 15. & 1960 & Un document ibatite inédit sur l'émigration des Nafüsa du Ğabal, Kraków 1960. \\
\hline 16. & 1961 & $\begin{array}{l}\text { Pages d'histoire du commerce trans-Saharien: les commerçants et le missionaires Ibädits au Soudan } \\
\text { central et occidental aux VIIIe-XIIe siècles, "Przegląd Orientalistyczny" 39: 1961, p. 3-18. }\end{array}$ \\
\hline 17. & 1962 & $\begin{array}{l}\text { L'État nord-africain de Tâhert et ses relations avec le Soudan occidental à la fin du VIIIe et au } \\
\text { IXe siècle, "Cahiers d'Études Africaines" } 8: 1962 \text {, vol. 2, p. 513-535. }\end{array}$ \\
\hline 18. & 1962 & $\begin{array}{l}\text { Arîsû, un nom de tribu énigmatique cité dans la lettre du roi khazar Joseph IXe siècle, "Cahiers } \\
\text { du monde russe et soviétique" } 3: 1962, \text { p. 90-101. }\end{array}$ \\
\hline 19. & 1964 & $\begin{array}{l}\text { Traits d'histoire du commerce transsaharien. Marchands et missionaires ibādites au Soudan } \\
\text { occidental et central au cours des VIIIe-Xe siècles, "Etnografia Polska" 8: 1964, p. 291-311. }\end{array}$ \\
\hline 20. & 1965 & $\begin{array}{l}\text { L'Afrique noire dans le Kitâb al-Masâlik wa I-Mamâlik d'Abù 'Ubayd al-Bakrî (XIème siècle), } \\
\text { "Africana Bulletin" } 2 \text { : 1965, p. 9-14. }\end{array}$ \\
\hline 21. & 1965 & $\begin{array}{l}\text { L'apport des sources arabes médiévales (IXe-Xe siècles) à la connaissance de l'Europe centrale } \\
\text { et orientale, "Settimane di studio del Centro Italiano di studi sull'Alto Medioevo" } 13: 1965 \text {, } \\
\text { p. 461-485. }\end{array}$ \\
\hline 22. & 1966 & Sur le nom de Dieu chez les Berbères médiévaux, "Folia Orientalia" $7: 1966$, p. 227-229. \\
\hline 23. & 1966 & $\begin{array}{l}\text { A propos de la genese du „Nuzhat al-mustaq fi, htiraq al-afaq” d'al-Idrisi, "Studi Magrebini”" } \\
1: 1966, \text { p. 41-55. }\end{array}$ \\
\hline 24. & 1967 & $\begin{array}{l}\text { arabes du Moyen âge au sujet des mines de pierres précieuses et de pierres fines } \\
\text { africain et de leur exploitation, "Africana Bulletin" } 7: 1967, \text { p. } 49-67 .\end{array}$ \\
\hline 25. & 1969 & $\begin{array}{l}\text { Arabic External Sources for the History of African South of the Sahara, Prace Komisji } \\
\text { Orientalistycznej 9, Wrocław } 1969 .\end{array}$ \\
\hline 26. & 1969 & Dzieje Afryki od czasów najdawniejszych do XIV w. Wybrane zagadnienia, Warsaw 1969. \\
\hline 27. & 1971 & The Ibadites in Arabia and Africa, "Journal of World History" 13 : 1971, p. 51-130. \\
\hline 28. & 1974 & West African Food in the Middle Ages: According to Arabic Sources, London 1974. \\
\hline 29. & 1974 & Arabic External Sources for the History of African South of the Sahara, ed. 2, London 1974. \\
\hline 30 & 1976 & $\begin{array}{l}\text { Marino San- udos Mappa mundi (1321) und die runde Weltkarte von al-Idrīsì (1154), "Rocznik } \\
\text { Orientalistyczny" 38: 1976, p. 169-176. }\end{array}$ \\
\hline 31. & 76 & Études maghrébines et soudanaises (Studia nad Maghrebem i Sudanem), Varsovie 1976. \\
\hline 32. & 1979 & $\begin{array}{l}\text { Les origines et l'islamisation de la ville de Tâdmakka d'aprčs les sources arabes, "Revue Française } \\
\text { d'Histoire d'Outre-Mer" } 46: 1979, \text { p. 163-168. }\end{array}$ \\
\hline 33. & 1979 & $\begin{array}{l}\text { A propos de deux études sur la géographie humaine du monde musulman, "Cahiers de civilisation } \\
\text { médiévale" } 22: 1979 \text {, no. 22-86, p. 173-190. }\end{array}$ \\
\hline 34. & 1983 & Études maghrébines et soudanaises (Studia nad Maghrebem i Sudanem) 2, Varsovie 1983. \\
\hline 35. & 1980 & Materiały pomocnicze do nauki języka arabskiego, Kraków 1980. \\
\hline 36. & 1991 & Lewicki Tadeusz: Le manuscrit No 277 de l'ancienne collection ibadite du feu Zygmunt Smogorz \\
\hline
\end{tabular}

It is impossible to make a detailed analysis of this huge, African Islam and Ibāḍi material included in Lewicki's works within the framework of the one presentation. Therefore, I will try to present the main achievements of Professor Lewicki, adding some critical notes. Thus my paper embraces a summary of assessments with several detailed examples. I am going to leave Lewicki's works on Arabic-Slavic contacts in the Middle Ages and the earliest Arabic sources describing aș-Ṣaqāliba - the Slavs. ${ }^{18}$

${ }^{18}$ Cf. Lewicki's works on Arabic-Slavic contacts: La voie Kiev-Vladimir (Włodzimierz Wotyński) d'après le géographe arabe du XII siècle, al-Idrīsī, "Rocznik Orientalistyczny" 13 : 1938, p. 91-105; Polska i kraje sąsiednie w świetle “Księgi Rogera," geografa arabskiego z XII w. al-Idrīsī'ego. Część 


\section{The contribution of professor Lewicki to ibāḍi studies}

It is now commonly known among researchers and experts in Islamic history that the spread of Ibāịyya in North Africa was caused by the collapse of this movement in the early caliphate. The Umayyads defeated Iraq and central Asia forcing them to emigrate to North Africa. There, in 776, the Ibādites founded a stable community, having its centre at Tāhert. Lewicki exerted a profound influence on the understanding of the Tāhert prosperity, the source of which was placed in the Ibāḍi control over long distance trade. His research shows that the west-northern African trade routes to bilād as-Sūdān existed largely thanks to the work of the North African Ibādites. Lewicki suggested that one of the earliest routes between Tāhert, Wargla and bilād

I: Uwagi ogólne, tekst arabski, thumaczenie (Pologne et les pays voisins dans le "Livre de Roger"), Kraków 1945; Ze studiów nad toponomastyka Rusi w dziele geografa arabskiego al-Idrisi'ego (XII w.). Sutaska-Sąciaska, "Sprawozdania z czynności i posiedzeń Polskiej Akademii Umiejętności" 48 : 1947, p. 404-407; Państwo Wiślan-Chorwatów w opisie al-Mas'udî'ego - Résumé, "Sprawozdania z Czynności i Posiedzeń Polskiej Akademii Umiejętności” 49 : 1948, p. 24-34; Pótnocna kraina Amazonek w opisach średniowiecznych geografów arabskich, "Sprawozdania z czynności i posiedzeń Polskiej Akademii Umiejętności” 49: 1948, p. 353-354; Osadnictwo słowiańskie w krajach muzulmańskich w świetle opisów średniowiecznych pisarzy arabskich, "Sprawozdania z czynności i posiedzeń Polskiej Akademii Umiejętności” 49: 1948, p. 487-490; Battyk w opisach autorów arabskich IX-X w. „Przegląd Orientalistyczny" 1 : 1949, p. 52-67; Zagadnienie Gotów na Krymie, "Przegląd Zachodni" 5-6 : 1951, p. 77-97; Polska i kraje sasiednie w świetle “Ksiegi Rogera," geografa arabskiego z XII w. al-Idrīsī'ego. vol. 2, Warszawa 1952; Osadnictwo stowiańskie i niewolnicy słowiańscy w krajach muzutmańskich w świetle opisów średniowiecznych pisarzy arabskich, "Przegląd Historyczny" 43 : 1952, p. 481-491; Ze studiów nad źródłami arabskimi. 1. Opis Stowiańszczyzny w dziele podróżnika arabskiego Abū Hamida al-Andalusiego," "Slavia Antiqua" 3 : 1952, p. 136-178; Skarb dirhemów arabskich z Piwonic koło Kalisza, "Wiadomości Archeologiczne" 19: 1953, no. 2-4, p. 136-156; Polska i kraje sasiednie w świetle "Księgi Rogera”" geografa arabskiego z XII w. al-Idrīsīego. Część II, Ilème partie, [Texte imprimé] La Pologne et les pays voisins dans le "Livre de Roger" de al-Idrīsī, géographe arabe du XII siècle, Warsaw 1954; Źródła hebrajskie do dziejów środkowej i wschodniej Europy w okresie wczesnego średniowiecza (IX-XIII w.), "Przegląd Orientalistyczny" 3 : 1955, no. 15, p. 283-300; Źródta arabskie do dziejów Słowiańszczyzny, Wrocław 1956; Skarb dirhemów arabskich z Czechowa, ed. A. Czapkiewicz, T. Lewicki, S. Nosek, Warszawa 1957; Il commercio arabo con la Russia e con i paesi slavi d'Occidente nei secoli IX-XI, "Annali dell'Istituto Universitario Orientale di Napoli" 1: 1959, p. 47-60; Die Vorstellungen arabischer Schriftsteller des 9. und 10. Jahrhunderts von der Geographie und den ethnischen Verhältnissen Osteuropas, "Der Islam“ 35 : 1960, p. 26-41; L'élevage des animaux domestiques chez les anciens Slaves d'après les sources arabes et persanes du IXe au XIII siècle, "Folia Orientalia" 3 : 1961-1962, p. 275-313; Les sources hébraïques consacrées à l'histoire de l'Europe centrale et orientale et particulièrement à celle des pays slaves de la fin du IXe jusqu'au milieu du XIII ${ }^{e}$ siècle, "Cahiers du monde russe et soviétique" 2 : 1961, no. 2, p. 228-241; Écrivains arabes du siècle IXe au XVI ${ }^{e}$, traitant de l'ambre jaune de la Baltique et de son importation en pays arabes, "Folia Orientalia" 4 : 1962, p. 1-39; Les rites funéraires païens des Slaves occidentaux et des anciens Russes d'après les relations des voyageurs et des écrivains arabes, "Folia Orientalia" 5 : 1964, no. 1-2, p. 1-74; Źródła arabskie do dziejów Słowiańszczyzny, Wrocław 1969; Dzieje polskich badań w zakresie numizmatyki orientalnej, [in:] Szkice z dziejów polskiej orientalistyki, vol. 3, ed. S. Strelcyn, Warsaw 1969; Handel Samanidów ze wschodnia i środkową. Europa, "Slavia Antiqua" 19: 1972, p. 1-18; Źródła arabskie do dziejów Słowiańszczyzny, vol. 2, part 2, (co-author: M. Czapkiewicz), Wrocław 1977. 
as-Sūdān was probably made at the end of the eighth or the beginning of the ninth centuries. ${ }^{19}$ At about the same time, the Tādmekka, Wargla, Tozeur and Qayrawān high road was probably in use while by the eleventh century, the third route from Wargla to the Mzab and Wādī Rìg became the central section of the commercial African infrastructure. ${ }^{20}$

Lewicki's conclusions were inspirations for the next generation of historians of Ibādiyya in West Africa. For example, Rev. Joseph Cuoq in his Histoire de l'islamisation de l'Afrique de l'Ouest des origines à la fin $d u X V I^{e}$ siècle states that the Ibādites from the Tripolitania region (where they had been trading with the inhabitants of the Lake Chad region, exchanging slaves and horses) were also involved in the western trade. The Ibādi traders from Tripoli, the Garīd (present day southern Tunisia), Qastiliya and Gadames continued commercial exchange of goods with the markets in Wargla, Zawīla, Tādmekka and Awdaghost in the $12^{\text {th }}$ century. Developing commercial and missionary activity, the Ibādites appeared in Gao probably already at the end of the eight century transforming Islam into the Ibādiyya version. This process is attested by al-Zuhri $\left(11^{\text {th }}-12^{\text {th }} \mathrm{cc}\right.$.) explaining that a part of the western Saharan population, from the Niger bend north to Tādmekka and Wargla, west to Siğilmāsa and south to Zafun, was converted to the Ibāḍi version of Islam during the eighth century. ${ }^{21}$ Joseph Schacht (1902-1969) gave new aspects, presenting how the Ibāditites from southern Tunisia, Wargla and Mzab spread the characteristic features of Islamic religious architecture across the Sahara. ${ }^{22}$ However, Professor Lewicki's contribution to the explication of the Ibạdi introduction of Islam into some part of sub-Saharan Africa was his great analyses of the North African Ibāḍi sources. These gave us interesting and credible evidence concerning the activities of merchants and the Ibādi missionaries in western and central Sudan from the eighth till the fourteenth century. ${ }^{23}$

Particularly interesting is the case of Zawīla, the African kingdom, which was only a part of the present-day eastern Fezzān (south-western region of modern Libya). Zawīla did not exist in the 660s when 'Uqbah ibn Nāfi' (622-683), the Arab

${ }^{19} \mathrm{Cf}$. T. Lewicki, L'État nord-africain de Tāhert et ses relations avec le Soudan occidental à la fin du VIII et au IXe siècle, "Cahiers d'Études Africaines" 8: 1962, vol. 2, p. 513-535.

${ }^{20} \mathrm{Cf}$. T. Lewicki, Traits d'histoire du commerce transsaharien. Marchands et missionaires ibâdites au Soudan occidental et central au cours des VIII - Xe siècles, "Etnografia Polska" 8 : 1964, p. 291-311; Les origines et l'islamisation de la ville de Tâdmakka d'après les sources arabes, "Revue Française d'Histoire d'Outre-Mer" 46 : 1979, p. 163-168.

${ }^{21}$ Cf. J. Cuoq, Histoire de l'islamisation de l'Afrique de l'Ouest des origines à la fin du XVI siècle, Paris 1984, p. 10, 15-18, 22-24, 45-49, 57, 101.

${ }^{22} \mathrm{Cf}$. J. Schacht, Sur la diffusion des formes d'architecture religieuse musulmane à travers le Sahara, "Travaux de l'Institut de Recherches Sahariennes” 11 : 1954, p. 11-27.

${ }^{23} \mathrm{Cf}$. T. Lewicki, Quelques extraits inédits relatifs aux voyages des commerçant et des missionaires ibādites nord-africains au pays du Soudan occidental et central au Moyen Age, "Folia Orientalia" 2:1960-1961, p. 1-27; T. Lewicki, L'État nord-africain de Tāhert et ses relations avec le Soudan occidental à la fin du VIII et au IXe siècle, "Cahiers d'Études Africaines" 8 : 1962, vol. 2, p. 513-535. 
hero and general who served the Umayyad dynasty, raided the Fezzān and Kawar. This region developed in the eight century, together with the growth of Muslim trade along the Chad-Tripoli route. One of the earliest Ibāịite centres, Tripoli, controlled over Zawīla. Although the 'Abbasid general Ibn al-Aša't attacked Zawīla and exterminated the Ibāịites there in 761-762 the region, however, remained an important centre of the Ibāḍiyya. It was attested in 891 by al-Ya'qūbī, reporting that all the people of Zawīla were Ibāḍīs. In 918-919, the chief of the Hawwāra tribe, 'Abd Allāh b. Hațạāb, conquered Zawīla and there he established a dynasty which survived until the end of the twelfth century. ${ }^{24}$ Concluding, the Ibādì sources refer to the trade between Taheret and Tadmekka. ${ }^{25}$

Lewicki's research shows that the Ibādītes of Zawila played a leading role in the African slave-trade. Moreover, it appears that some of the blacks who settled in North Africa in that period were the Ibāḍ̄ Muslims. The Ibāḍite sources attest that, for example referring to a community in Ğabal Nafūsa known as Ĭgnāw(un), which could be read as Ignaun, the plural of agnaw, meaning "blacks." Some eminent Ibāọ̄i shaykhs, including Abū 'Ubayda al-Ḥamīd al-Ğanāwnī, originated from this community. In 811-12, the latter was appointed by the imām of Tahert as his representative ( 'âmil) in Ğabal Nafūsa. It is said that he could speak three languages: Arabic, Berber and the language of Kanem (al-lugia al-kānimiyya). ${ }^{26}$

Thus we have reached the very interesting research of Lewicki Études ibādites nord-africaines. Partie I: Tasmiya Šuyūh̆ Ğabal Nafūsa wa-qurāhum. Liste anonyme des šaỵ̣s ibāḍites et des localités du Ğabal Nafūsa contenue dans le 'Siyar al-mašă’ị̣' $\left(\mathrm{VI}^{\mathrm{e}}-\mathrm{XII}{ }^{\mathrm{e}} \mathrm{s}.\right),{ }^{27}$ which requires serious considerations. This work consists of an elaborate commentary on four pages of the Ibāḍi manuscript belonging to the Lwów collection, collected by the late Zygmunt Smogorzewski (1884-1931), Lewicki's master, who was Russia's vice-consul in Algeria in the Tsarist times. ${ }^{28}$ Professor

${ }^{24}$ Cf. T. Lewicki, The Role of the Sahara and Saharians in the Relationships between North and South, [in:] General History of Africa, vol. 3: Africa from the $7^{\text {th }}$ to the $11^{\text {th }}$ Century, ed. I. Hrbek, London 1992, p. 151; J. D. Fage, The Cambridge History of Africa, vol. 2 c. 500 B.C. - A.D. 1050, New York 1978, p. 643.

${ }^{25}$ Cf. T. Lewicki, The Ibadites in Arabia and Africa, "Journal of World History" $13: 1971$, p. 117.

${ }^{26}$ Cf. T. Lewicki, Études ibādites nord-africaines. Partie I: Tasmiya Šuyūh Ğabal Nafūsa waqurāhum..., p. 92-96.

${ }^{27}$ T. Lewicki, Études ibāḍites nord-africaines. Partie I: Tasmiya Šuyūh̆ Ğabal Nafūsa wa-qurāhum. Liste anonyme des šay ḥs ibā dites et des localités du Ğabal Nafūsa contenue dans le 'Siyar al-mašă 'iḥ' $\left(V I^{e}-X I I^{e}\right.$ s.) Texte arabe avec introduction, commentaire et index, "Prace Orientalistyczne" IV, Warsaw 1955.

${ }^{28}$ Zygmunt Smogorzewski as the Russian vice-consul in Alger (1913) was interested in exploring the Ibāḍ̄ history having many contacts with the Ibāḍ̄ elites. During his second stay in Algeria (Mzab) in 1925-1926 he gathered many Ibāḍī sources manuscripts. Cf. A. Kuczyński, Korzenie i wspótczesność polskich badań etnologicznych w Afryce, "Etnografia Polska" 38 : 1994, no. 1-2, p. 142. 
Lewicki inherited this unexplored collection, but unfortunately these manuscripts disappeared during the Second World War. ${ }^{29}$

The four pages of the Ibāḍi manuscript, which Lewicki examined, contain a list of the Ibādị leaders (šuy ūh ) from the Ğabal Nafūsa with their villages of origin compiled in the twelfth century. In this publication Professor Lewicki gathered, apparently exhaustively, all the references to these people and places with some commentaries of his own. He analyzed mostly the component parts of the Ibādī sources. The author of Études ibädites nord-africaines should be congratulated on his determination, which led him successfully through the barren areas of the Ibādī bibliography. It need to be said Lewicki found help in Henri Basset's work Sanctuaires et forteresses almohades ${ }^{30}$ and Jean Despois's research Le Djebel Nefusa. ${ }^{31}$ The next valuable contribution of this book is the identification of the sites of numerous villages on the map. On the other hand, not all of Tadeusz Lewicki's philological speculations have found acceptance. For example, orientalists should like to see more evidence that the name Māmad is the Berberized form of Muhammad, that the لبu derives from Wahb Allāh and that $W \bar{u} f \hat{\imath}$ is to be regarded as a Berber not as an Arab name. ${ }^{32}$

\section{Critical study of historical sources}

Since the time of the foundation of the Association for Promoting the Discovery of the Interior Parts of Africa in 1788 much has been written about the European "discovery of Africa," which began in London. In more recent times, especially in the early $20^{\text {th }}$ century, scholars used another expression: "invention of Africa" - imaging the continent and its people by colonial administrators, some scholars, journalists and novelists. But there was a much earlier "discovery" of Sub-Saharan Africa and its similar "invention" by Arabs and Berbers using the Arabic language to express their thoughts.

This part of Lewicki's West African studies concerns the question of these sources. Naturally, in the 1950s and 60s, in the circles of orientalists and historians some sources concerning the medieval Sub-Saharan Africa studies were known. Geographical accounts with historical information were given by al-Ya 'qūbī (died 897/898), a Berber Muslim geographer and perhaps the first historian of medieval Islam of the ninth century ${ }^{33}$ Ibn Hawqal (c. 920-990) in his Șürat al-ard of the

${ }^{29}$ Cf. A. Zaborski, Min bilād aṣ-Șaqāliba ilā bilād as-Sūdān-od Stowiańszczyzny po Sudan. Prof. Tadeusza Lewickiego dorobek arabistyczny..., p. 7; J. F. P. Hopkins, Short Notice: Tadeusz Lewicki, "Bulletin of the School of Oriental and African Studies" 19: 1957, p. 411.

${ }^{30}$ Cf. H. Basset, H. Terrasse, Sanctuaires et forteresses almohades, Paris 1932.

${ }^{31}$ Cf. J. Despois, Le Djebel Nefousa (Tripolitaine) - étude géographique, Paris 1935.

${ }^{32}$ Cf. J. F. P. Hopkins, Short Notice: Tadeusz Lewicki..., p. 411.

${ }^{33}$ Cf. Kitâb al-a lâk an-nafìsa VII auctore Abû Alî Ahmed ibn Omar Ibn Rosteh et Kitâb al-boldân auctore Ahmed ibn ab̂̂̀ Jakûb ibn Wâdhih al-Kâtib al-Jakûbî Kitāb al-Buldān, ed. M. J. de Goeje, Lugduni Batavorum 1892. 
tenth century, ${ }^{34}$ and the work of the great eleventh century al-Bakrī (c. 914-994). ${ }^{35}$ To these we should add Taheret, the ninth century testimony of Ibn al-Sagīir. ${ }^{36}$ The principal representative of the Ibāḍi tradition was the sixteenth-century aš-Šammāhn̄, Kitāb al-siyar. ${ }^{37}$ Professor Lewicki enriched this area of historic sources of the West African medieval period by publishing the supplements: Une chronique ibädite: "Kitāb al-siyar" d'Abu 'l-Abbās Aḥmad aš-Šammāhn̄ $\bar{l}^{8}$ and Quelques extraits inédits relatifs aux voyages des commerçants et des missionaires ibädìtes nord-africains au pays du Soudan occidental et central au moyen âge. ${ }^{39}$

The medieval references to tropical Africa written by Arabic authors are characterized by a wide variety of specific historical contexts. The external written evidence on the Sahelian and Sudanic zones of West Africa in medieval period shows a tendency to view the region through the lenses of Islam and at the state level. One can observe this tendency reading the classical Arabic sources describing Africa. Following to the tremendous undertaking to publish all medieval Sub-Saharian references, made in 1962 by the major figure of all African Studies in the Czech Republic Ivan Hrbek (1923-1993), ${ }^{40}$ Professor Lewicki published the edition of Arabic External Sources for the History of Africa to the South of Sahara in $1969 .{ }^{41}$ Developing this topic it is necessary to take note of the nature of Arabic writing about sub-Saharan Africa and its relationship to the Greek knowledge and legend. First of all, the Arab' encounter with Africa did not begin in the medieval Islamic period but probably much earlier. For example, it is not entirely clear what the term Habaš̄ meant in the early Islamic period, but probably it simply meant an individual who originated from somewhere under the control of the kings of Axum. According to the medieval Arab geographers the name Habaša refers sometimes to a much wider area than kingdom

${ }^{34} \mathrm{Cf}$. Opus geographicum: secundum textum et imagines codicis constantinopolitani conservati in bibliotheca antiqui palatii $N^{\circ} 3346$ cui titulus est "Liber imaginis terrae" / auctore Ibn Haukal (Abū 'l-Kāsim Ibn Haukal al-Nașībī), ed. J. H. Kramers, Lugduni Batavorum 1938.

${ }^{35} \mathrm{Cf}$. Description de l'Afrique septentrionale par el-Bekri, ed. Mac Guckin de Slane, Alger-Paris 1911-1913.

${ }^{36}$ Cf. Chronique d'Ibn Saghir sur les imams rostemide de Tahert, ed. A. de Calassanti-Motylinski, Paris 1907.

${ }^{37} \mathrm{Cf}$. A. de Calassanti-Motylinski, Bibliographie du Mzab. Le livre de la secte abadhite, "Bulletin de Correspendance Africaine" 3 : 1885, p. 47-70.

${ }^{38}$ Cf. T. Lewicki, Une chronique ibādite: "Kitāb al-siyar" d'Abu 'l-Abbās Ahmad aš-Šammāhn̄, "Revue des Etudes Islamiques" 1 : 1934, p. 59-78.

${ }^{39} \mathrm{Cf}$. T. Lewicki, Quelques extraits inédits relatifs aux voyages des commerçant et des missionaires ibādites nord-africains au pays du Soudan occidental et central au Moyen Age, "Folia Orientalia" 2: 1960-1961, p. 1-27.

${ }^{40}$ Cf. J. Záhořík, African Studies in the Czech Republic-from the early Czech-African contacts until the 21st century, "Afrikanistic online" 2006: http://www.afrikanistik-online.de/archiv/2006/596/ (quoted 12.07.2012).

${ }^{41}$ Cf. T. Lewicki, Arabic External Sources for the History of Africa to the South of Sahara, Prace Komisji Orientalistycznej 9, Wrocław 1969; Arabic External Sources for the History of Africa to the South of Sahara, ed. 2, London 1974. 
of Axum, and includes the land to the south of the Fezzan and west of Lake Chad. It is evident that it echoed the old Greek usage of the term Aethiopia as a generic name for the territories and peoples to the south of Libya and Egypt.

Lewicki's work Arabic External Sources for the History of Africa to the South of Sahara presents basic Arabic material on Sub-Saharian Africa. The presentation embraces sources from the eighth century when the whole length of the Mediterranean fringe of Africa belonged to the Islamic World under the Abbasid rule. Arab forces also penetrated into or even beyond the Saharan confines; the Fezzan in the south of modern Libya was subdued as well as Moroccan Sūs down to the Dra' valley. It was at such points that incoming Arabs began to learn about the existence of peoples living beyond the sea of sand.

It is worth stressing that we dispose only a small handful of truly first-hand accounts of medieval sub-Saharan Africa: the tenth-century historian-encyclopædist

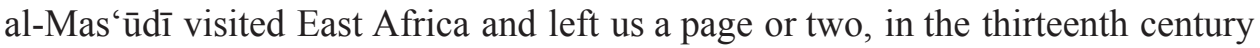
Ibn Sa'îd quoted passages from the apparently lost travel account relating to the Lake Chad area, while in the mid-fourteenth century the intrepid Ibn Battututa visited Mali, the Niger Bend and Tagidda (present day Niger) and wrote an account of the trip in the last section of his travel memoirs. Finally, we should not forget that some amount of Arabs' knowledge about various Sub-Saharian regions was gained from Greek sources. ${ }^{42}$

Finally, it is important to add that the editions of Lewicki's Arabic External Sources for the History of Africa to the South of Sahara gave an impulse to continue the publication of later sources, which Rev. John Donnelly Fage (1921-) did in his A guide to Original Sources for Precolonial Western Africa Published in European Languages. ${ }^{43}$

\section{Research on social and economic life in sub-Saharan Africa}

Lewicki also made use of the medieval Arabic sources, especially historical and geographic works which recorded a great deal of information about social and economic life in Africa and related to foodstuffs and the preparation of food. West

${ }^{42}$ Cf. J. Hunwick, A Region of the Mind: Medieval Arab Views of African Geography and Ethnography and Their Legacy, "Sudanic Africa" 16 : 2005, p. 103-108; J. Cameron Monroe, A. Ogundiran, Power and Landscape in Atlantic West Africa: Archaeological Perspectives, Cambridge 2012, p. 309-313.

${ }^{43}$ Cf. J. D. Fage, 1921- (John Donnelly), A Guide to Original Sources for Precolonial Western Africa Published in European Languages: for the most part in book form African Studies Program, University of Wisconsin-Madison 1994. Sources 1501-1550, p. 7-13; 1551-1600, p. 14-28; 1601-1625, p. 29-36; 1626-1650, p. 37-42; 1651-1675, p. 43-44; 1682-1700, p. 53-61; 1701-1725, p. 62-68; 1726-1750, p. 69-77; 1751-1775, p. 78-85; 1776-1800, p. 86-104; 1801-1826, p. 105-126; 1826-1850, p. $127-155 ; 1851-1865$, p. 156-171. Sources after 1865 , p. 172-173ff. 
African Food in the Middle Ages: According to Arabic Sources ${ }^{44}$ is a significant book, especially for specialists, particularly social and economic historians, studying West Africa before the sixteenth century. It answers the question what the basic foods were before the arrival of crops from the Americas such as maize, cassava, ground nuts, red peppers and tomatoes. Lewicki did not only collect references from the Arabic texts but also interpreted them in the light of works of modern ethnographers and descriptions given by travellers in more recent times. It is one of the Oriental books which raised many questions, and led to diverse opinions. ${ }^{45}$

Lewicki attempted to reconstruct the economic basis of West African society between the 10th and 16th centuries "to see approximately what the food of the population of West Africa was prior to the great changes which took place in the agricultural economy [...] during the sixteenth to eighteenth centuries." ${ }^{\prime 4}$ On the basis of the sources of 15 Arab authors, who noted the diets of the countries they described, Lewicki scanned the texts for information falling into four main categories:

a) vegetable foodstuffs, including wild plants, truffles, manna, and methods of preparing cereals as food;

b) meat and fish, including game animals;

c) other foodstuffs, such as fats, cheese, honey, sugar, spices and beverages;

d) utensils.

Lewicki's analyses present the indigenous and ancient nature of West Sudanic grain cultivation, probably including rice and the effects of collecting wild plant foods, among which we find congeners of domesticated grains. The author of the West African Food describes this phenomenon as a dynamic interaction between North and West Africa. It has resulted in the increase of the spread of certain important cultigens from the north to the south.

${ }^{44}$ Cf. T. Lewicki, West African Food in the Middle Ages: According to Arabic Sources, London 1974. Foreword: by J. D. Fage, p. VII-X; Acknowledgements, p. X-XI; Map of West and North Africa in the Middle Ages, p. XII-XVI; Transcription and pronunciation of Arabic words: p. XVXVI; Introduction: p. 1-12; 1: Arabic sources for the history of the foodstuffs used by West African peoples: p. 13-18; 2: Vegetable foodstuffs: p. 19-78; 3: Meat and fish: p. 79-104; 4: Other foodstuffs: p. 105-131; 5: Utensils: p. 132-133; Conclusion: p. 134-134; Notes: p. 135-226; Bibliography: p. 227-242; General index: p. 243-256; Index of authors etc., cited: p. 257-262.

${ }^{45}$ Cf. L. Siroto, Notice: Tadeusz Lewicki, West African Food in the Middle Ages: According to Arabic Sources, "American Anthropologist" 78 : 1976, p. 420; H. T. Norris, Review of Tadeusz Lewicki "West African Food in the Middle Ages According to Arabic Sources," "Bulletin of the School of Oriental and African Studies" 38 : 1975, p. 693-694; "African Affairs" 74 : 1975, no. 297, p. 491-492; D. Birmingham, Shorter Notice: Tadeusz Lewicki "West African Food in the Middle Ages According to Arabic Sources," "The Journal of African History" 18 : 1977, p. 154-155; A. H. M. KirkGreene, Review of Book: History, West African Food in the Middle Ages, According to Arabic Sources. By Tadeusz Lewicki, “Africa" 47 : 1977, p. 226-227; B. M. Perinbeam, Review of Book: West African Food in the Middle Ages by Tadeusz Lewicki, "The Journal of Economic History" 35 : 1975, p. 676-677.

${ }^{46}$ Cf. T. Lewicki, West African Food in the Middle Ages: According to Arabic Sources..., p. 134. 
Some of Lewicki's opinions about West African food have been widely accepted by the mainstream Orientalist scholarship community but other results of this research indicate ambivalence. Firstly, the earliest surviving Arabic reference to the West African Bilād as-Südān, which can be translated as "the land of the black man," generally speaking about the area that lies to the south of the Sahara, dates from the eighth century. From the ninth and tenth centuries onwards, there appeared a considerable corpus of Arabic geographies, histories and travellers' accounts containing various information about the Bilād as-Südān. But one should not overlook the fact that this information has limitations. The Arabs' knowledge of West Africa was, as a matter of fact, limited to the savannah region of the Sudan that was approachable from the Sahara, and hardly extended to the southern region, the forest zones commonly known as Guinea. Much of this knowledge among the Arabs and Berbers was not first hand.

Secondly, according to Professor Lewicki the middle ages include the period from circa the 10th century up the publication by Joannes Leo Africanus' (or alḤasan ibn Muḥammad al-Wazzān al-Fāsī c. 1494 - c. 1554?) Description of Africa in 1526, the last original author of Arab background to write about West Africa. But in order to fill gaps in the descriptions in his basic medieval sources, Lewicki used a great number of diverse European sources, ranging from the 16th century to the present. For him they were the evidence required to establish a claim concerning the continuity and the specific identity of medieval African crops and practices. Sometimes some authors argue on the basis of this complementary material, which carries his discourse "beyond tentative evaluation into assumptions that axe not sustained by facts and that occasionally suggest special pleading." ${ }^{47}$ Going beyond the limits of the title of his work Lewicki showed abundant second-hand material, from the later 19th century travellers, in particular Heinrich Barth (1821-1865), Gustav Nachtigal (1834-1885) and Friedrich Gerhard Rohlfs (1831-1896). The results of this practice "still remain frustrating for anyone wishing to evaluate and quantify the importance of individual crops at any particular place or time." ${ }^{\prime 4}$

Thirdly, the composition of this book is also problematic. The discussion about the value of Arabic sources is really too long and incomplete. But it is astonishing how short is his conclusion, which takes up less than a page after several chapters on vegetable foodstuffs, meat and fish, utensils and other foodstuffs. This conclusion "ends by reminding us that we still do not know all the answers: above all we must await conclusions drawn from West African archaeological evidence." ${ }^{49}$

${ }^{47}$ Cf. L. Siroto, Notice: Tadeusz Lewicki, “West African Food in the Middle Ages”..., p. 420.

${ }^{48}$ Cf. D. Birmingham, Shorter Notice: Tadeusz Lewicki “West African food in the Middle Ages”..., p. 155.

${ }^{49}$ Cf. A. H. M. Kirk-Greene, Review of Book: History, “West African Food in the Middle Ages"..., p. 226. 
Professor Lewicki explained many historical questions concerning West Africa; some of them were quite a mystery for scholars at that time. His research has been widely accepted by the mainstream scientific community. Even after his death Professor Lewicki remains one of the most influential Oriental scholars in Poland and Europe, which is confirmed by thousands of web pages quoting Lewicki's works. He was also the author of the article Al-Iba $\bar{d} \bar{l} \bar{y} y$ in the famous publication Handwörterbuch des Islam, edited by A. J. Wensinck, J. H. Krammers ${ }^{50}$ and Lewicki's research was quoted as basic literature for the Ibādīte studies in the second edition of Encyclopcedia of Islam ${ }^{51}$ and in Medieval Islamic Civilization, an Encyclopedia. ${ }^{52}$

\section{Summary}

\section{The contribution of prof. Tadeusz Lewicki (1906-1992) to Islamic and West African studies}

Prof. Tadeusz Lewicki (the member Académie des Sciences d'Outre-Mer, Association Internationale d'Études des Civilisations Méditerranéennes, Royal Asiatic Society) was not only one of the most famous scholars of Oriental studies in Poland 20th century but also one of the top experts on the history of the Ibadites. For example, he has gathered exhaustively all the references to Ibadites and placed with a certain amount of commentary of his own (Études ibadites nord-africaines, part 1. Warsaw 1955). He has studied and published Arabic sources (mostly Ibādīi) on the history of the Ibadites and of the Slavic peoples and cataloged eighth- and ninth-century Arab coins found on Polish territory (Arabic External Sources for the History of Africa to the South of Sahara, Wrocław 1969; Polska i kraje sasiednie w świetle "Księgi Rogera" geografa arabskiego z XII w. al-Idrīsì'ego, parts 1-2. Warsaw, 1945-54; Źródła arabskie do dziejów stowiańszczyzny, vols. 1-2. Wrocław 1956-69). Professor Tadeusz Lewicki attempts to reconstruct also the economic base of West African society between the 10th and 16th centuries (West African Food in the Middle Ages: According to Arabic Sources, London 1974). His basic sources are 15 Arab authors, all of whom noted the diet of the countries they described.

The purpose of this paper is to provide a review and critical analysis of Lewicki's researches and answer which of his interpretations and philological speculations still have found acceptance. This paper also respect to how Lewicki supports, extends, and qualifies the previous literature on West African, Islamic and Ibadites study, and how gives directions for future research.

\section{Keywords}

Ibadites, Islam, Polish Orientalists, Sub-Saharan Africa, West Africa

${ }^{50}$ Cf. T. Lewicki, Al-Ibāạ̄ya, [in:] Handwörterbuch des Islam, ed. A. J. Wensinck, J. H. Krammers, Leiden 1941, p. 179-181.

${ }^{51}$ Cf. G. Iver, Berberes - after Islam, [in:] Encyclopcedia of Islam, $2^{\text {nd }}$ edition, ed. P. J. Bearman, Th. Bianquis, C. E. Bosworth, E. van Donzel, W. P. Heinrichs, vol. I, Leiden 1960, col. 1176.

${ }^{52}$ Cf. C. Barnes, Ibadis, [in:] Medieval Islamic Civilization, an Encyclopedia, ed. J. W. Meri, New York 2006, p. 341-342. 
